\title{
仮想車両を用いた車両群の合流制御*
}

宇野 篤也** ·阪口 健*** ·津川 定之***

\section{Merging Control of Automated Vehicles Based on Virtual \\ Vehicles*}

\author{
Atsuya UnO**, Takeshi SaKaguchi*** and Sadayuki Tsugawa***
}

\section{1.はじめに}

特に高速道路における自動車走行の安全と効率を両立 させるためには, 単路に扔ける定常的な車両の走行制御 だけでなく, 合流時や車線変更時における車両の走行制 御が必要である。単路における車両の走行制御について は多くの研究が行われているが1), ランプから本線への合 流時の制御に関しては小数の研究があるだけである2),3).

この速報は, 高速道路においてランプから本線に合流 する車両群が本線上の車両群に合流するときの制御アル ゴリズムについて考察している。ここで提案する合流制 御アルゴリズムは車両間通信を前提とし，ランプ上また は本線上の車両を本線上またはランプ上に投影した仮想 車両に対する車間距離制御に基づいている.

\section{2. 合流制御}

\section{1 合流制御の原理}

車線を走行する車両が他車線からの車両と安全にかつ 円滑に合流するためには, 合流前に合流後の車間距離を 確保する必要がある。しかし，合流しょうとする車両は それぞれ異なる車線上に存在するため, そのままでは車 間距離を確保することは困難である。この問題を解決す るために，ここでは自車線上に投影した相手車両に対し て車間距離制御を行うことを考える。この自車線上に投 影した車両のことを仮想車両と呼ぶことにする.

\section{2 合流パターンの分類}

単独車両が複数台の車両からなる群に合流する場合を 考える．合流を合流路における合流と車線変更による合

* 原稿受付 1998 年 5 月 11 日

**筑波大学 連携大学院 工学研究科 Doctoral Program in Engineering, University of Tsukuba; Tsukuba-shi, Ibaraki 305-8573, JAPAN

*** 通産省工業技術院 機械技術研究所 Mechanical Eng. Lab. , AIST MITI; Namiki 1-2, Tsukuba-shi, Ibaraki 305-8564, JAPAN

Key Words: merging control, inter-vehicle communication, platoon, longitudinal control.
流の二つの場合に分けて考える.

\subsection{1 合流路における合流の場合}

簡単のために 1 レーンのランプが一ケ所で 1 レーンの 本線に合流するものとする。この場合, 合流パターンを Fig. 1 に示す 3 パターンに分類することができる.

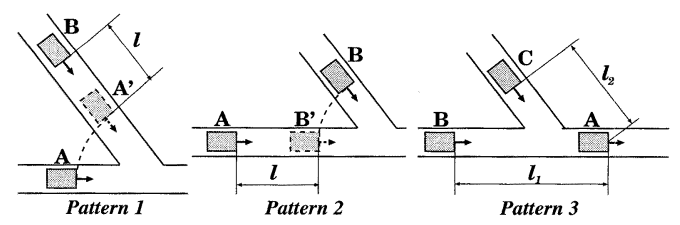

Fig. 1 Merging at a ramp

-パターン 1: 支線の車両が本線の車両の後方で合流 する場合

- パターン 2: 支線の車両が本線の車両の前方で合流 する場合

・パターン $3:$ 支線の車両が本線の車両群の間に入る 場合

車両群に車両が，衝突することなくスムーズに合流す るためには, 合流地点を通過するまでに十分な車間距離 を確保する必要がある。

\subsection{2 車線変更による合流の場合}

簡単のため車線変更は隣接した車線間で一方の車線か らのみ行うものと仮定する。この場合も合流路に招ける 合流の場合と同じように, 合流パターンを Fig. 2 の 3 パ ターンに分類する.

・パターン 1: 目標車線上の車両が自車の前方に位置 する場合

- パターン 2 : 目標車線上の車両が自車の後方に位置 する場合

・パターン $3:$ 目標車線上の車両群の間に自車が割り 込む場合

合流路における合流の場合, 合流地点に到達するまで に合流準備を完了させる必要があるが, 車線変更による 


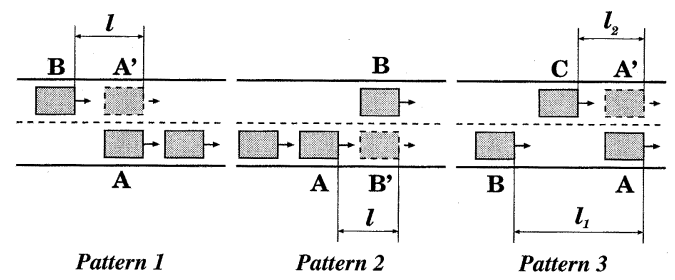

Fig. 2 Merging on lane changing

合流の場合には合流準備が完了し次第合流を行うことに なるそそのために，合流される側から合流する側に対し て合流準備が完了したことを知らせる必要がある。この 情報は車両間通信により伝達することになる。

\section{3 パターン別合流方法}

Fig. 1と Fig. 2より, 合流路における合流と車線変更に おける合流の場合も基本的に同じ合流パターンで扱うこ とが可能なことがわかる.

各合流パターンにおける合流方法を以下に示す.

(1) パターン 1

合流が完了した状態において, 合流を行う車両 B は車 両 Aの後方に位置することになる. 安全にかつ円滑に合 流するためには, 後続車両 B は合流を完了するまでに, 先行車両 $\mathrm{A}$ とのスペースヘッドウェイを $L$ (設定スペー スヘッドウェイ）以上にする必要がある。 そのために, 後 続車両 $\mathrm{B}$ は, 先行車両 $\mathrm{A}$ を自車線上に投影した仮想車両 $\mathrm{A}^{\prime}$ を生成し,この仮想車両 $\mathrm{A}^{\prime}$ に対して車間距離制御を 行いスペースヘッドウェイを $L$ に調整する。このとき後 続車両 B は先行車両 A の情報を必要とする.

(2) パターン 2

合流が完了した状態に扔いて, 合流を行う車両 B が車 両 Aの前方に位置することになる。この場合には後続車 両 $\mathrm{A}$ は合流が完了するまでに, 先行車両 $\mathrm{B}$ とのスペース ヘッドウェイを $L$ 以上にしなくてはならない。この場合 はパターン 1 の場合と逆に, 後続車再 $\mathrm{A}$ は自車線上に仮 想車両 B'を投影しスペースヘッドウェイを確保する．

(3) パターン 3

合流を行㧍うとする単独車両 $\mathrm{C}$ が，合流先を走行する 車両群に割り込む形になる。合流される側の車両 A と合 流を行う車両 $\mathrm{C}$ の位置関係はパターン 1 の場合と同じで あり, 車両 $\mathrm{C}$ は自車の前方に仮想車両 $\mathrm{A}^{\prime}$ を作成し，ス ペースヘッドウェイの調整を行う.

車両 $\mathrm{C}$ は車両 $\mathrm{B}$ の前方に割り达む形になる。このと き, 車而 $\mathrm{A}$ と車両 $\mathrm{B}$ 間のスペースヘッドウェイを最終的 には $2 L$ 以上にする必要がある。

いずれの合流パターンにおいても，仮想車両に対する 車間距離制御アルゴリズムと仮想車両を生成するための
対象車両に関する情報が必要となり，その情報の伝達は 車両間通信を用いることになる。

\section{3. シミュレーション}

\section{1 車間距離制御アルゴリズム}

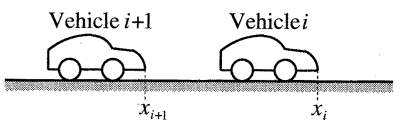

Fig. 3 Platooning of vehicles

一列に走行している車両列の先頭を 1 番とし, 以下 2 , $3,4, \cdots, i, \cdots$ と番号をつける (Fig. 3 )。 このとき, 車 両 $i$ の動特性を最も簡単な形式で次のように表す.

$$
\ddot{x}_{i}=u_{i}
$$

ここで, $x_{i}$ と $u_{i}$ は車両 $i$ の位置と制御入力を表してい る. 車両 $i$ と $i+1$ との設定スペースヘッドウェイを $L$ とした時の各車両の位置偏差を $e_{i}$ で表すと, 偏差 $e_{i}$ は 次のようになる。

$$
e_{i}=\left(x_{i}-x_{i+1}\right)-L
$$

(1)，(2) 式より，位置偏差 $e_{i}$ に関する次の方程式が導 き出される。

$$
\ddot{e}_{i}=u_{i}-u_{i+1}
$$

この位置偏差システムに対し，Fig.4に示すような PD 制御によるフィードバック制御系を構成する。制御系の 設定值は 0 である。ここで, $k_{1}$ と $k_{2}$ は決定すべきフィー ドバックゲインである。

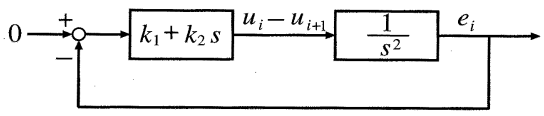

Fig. 4 Longitudinal control system

極配置法4) から, 車両 $i+1$ への制御入力 $u_{i+1}$ は,

$$
u_{i+1}=u_{i}+k_{1} e_{i}+k_{2} \dot{e}_{i}
$$

となる。

この研究では, 車間距離制御だけを考え，ラテラル制 御は考えない。

\section{2 通信システム}

(4) 式で表される車間距離制御アルゴリズムは, 仮想 車両の絶対位置と速度の情報を必要とすることがわかる． これらの情報は合流前に直接車両間通信や路車間通信を 
経由した車両間通信を用いて合流車両間で交換する必要 がある。

\section{3 シミュレーションと結果の考察}

Fig. 5 に示すようなコースを想定し，合流路における 合流と車線変更による合流のシミュレーションを行った。 各車両群の先頭車両は一定速度 $22.2 \mathrm{~m} / \mathrm{s}(80 \mathrm{~km} / \mathrm{h})$ で 走行しながら合流し，後続車両は $20 \mathrm{~m}$ のスペースヘッド ウェイを保ちつつ追従走行を行うものとした．通信可能 距離は $200 \mathrm{~m}$, 加速度の許容範囲は $\pm 0.1 \mathrm{G}$, 通信周期と 制御周期は同期させ，それぞれ $0.01 \mathrm{~s}$ とした. Fig. 6 に各 車群の加速度および速度変化を, Fig. 7 に合流地点から の相対距離を示す。
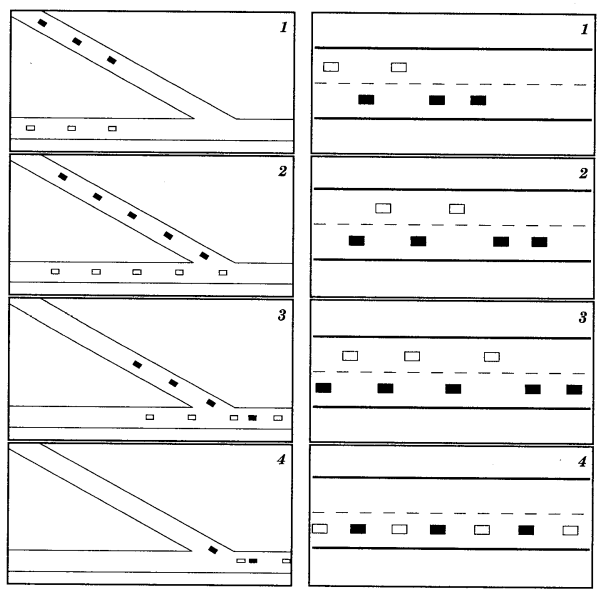

Fig. 5 Simulation results: merging at a ramp (left) and on lane changing (right)

これらシミュレーションの結果は, 二つの車両群が合 流するまでに個々の車両が十分なスペースヘッドウエイ を確保し，円滑な合流が可能なことを示している.

Fig. 6 に打いて 20 30 秒付近で加速度が激しく変化し ているが，これは合流前と合流後で追従対象が変わるか らである。このような急激な加減速は望ましくない。こ れは新しい追従対象に対する初期值を適切に設定するこ とにより，改善が可能である.

\section{4. おわりに}

この速報では仮想車両を用いた二つの車両群の合流ア ルゴリズムを提案し，シミュレーションで検討した。合 流路に扔ける合流と車線変更による合流を同一のアルゴ リズムで取り扱うことが可能であることを示し，簡単な モデルと車間距離制御アルゴリズムでシミュレーション を行いその有効性を確認した。この手法を実際の高速道 路に適用するためには，車而間通信のプロトコルや車間 距離制御アルゴリズムの高度化を考虑する必要がある.
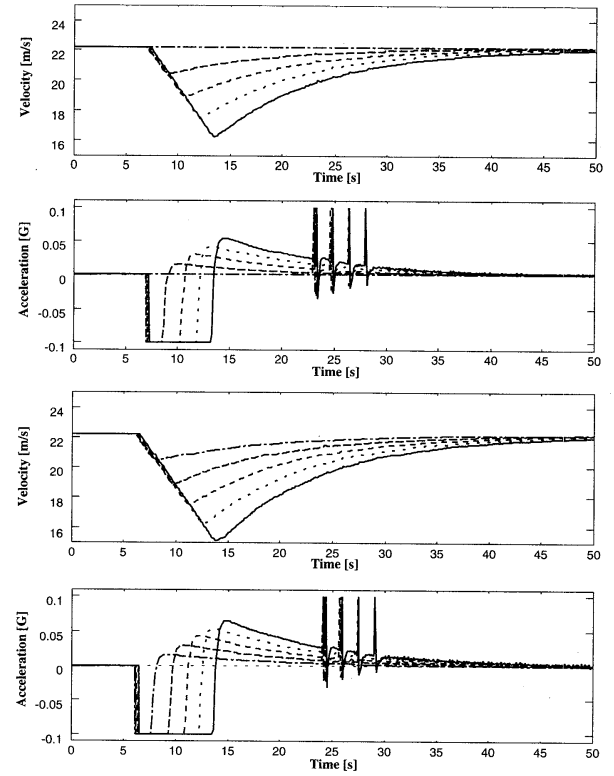

Fig. 6 Velocities and accelerations of vehicles

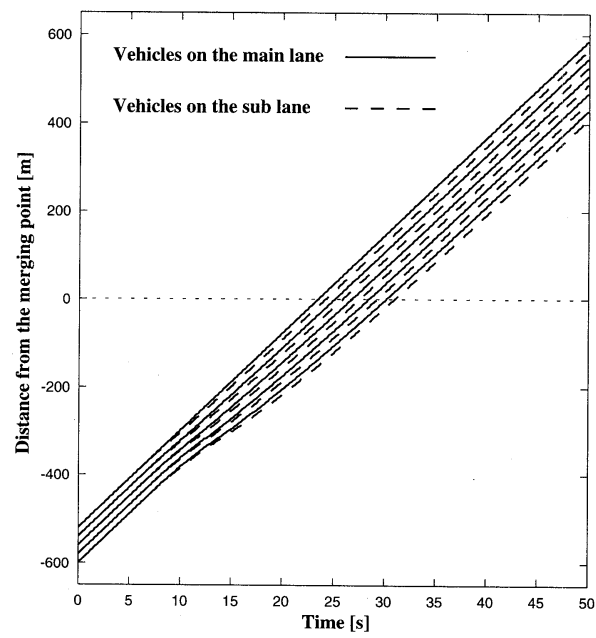

Fig. 7 Trajectories of two platoons

\section{参考文献}

1) S. Shladover: Review of the state of development of Advanced Vehicle Control Systems (AVCS) ; Vehicle System Dynamics, 24, pp. 551-595 (1995)

2) M. Papageorgiou (Ed.): Merging control; Concise Encyclopedia of Traffic \& Transportation Systems, Pergamon Press, pp. 257-263 (1991)

3) PATH; AHS Entry/Exit Implementation; Precursor Systems Analysis of Automated Highway Systems, US DOT (CD-ROM) (1997)

4) 津川·村田·広瀬·谷田部：車両間通信による自律車両群の走行 制御; 計測自動制御学会論文集, Vol. 26, No. 9, pp. 10581065 (1990) 